\title{
原著論文
}

\section{XML Web Service化によるレガシーモデルの統合}

\author{
吉田智一・高橋英博・大原源二
}

農業技術研究機構近畿中国四国農業研究センター テ 721-8514 広島県福山市西深津町 6-12-1

\section{要旨}

インタネット環境において不足している農業関係のWebコンテンツを充実させる目的で, 個別マシン で動作する既存の各種農業生産支援プログラム (レガシーモデル) の有効利用を図り, インタネット上 での共有化・モデル統合を可能とする手法について検討した. 最初に, レガシーモデルのWeb対応化に 際して適用可能な各種のWeb関連技術について比較検討した. 次に, XML Web Serviceによるレガシー モデルのWeb 対応化を検討するために, 一つの題材としてWindows NT/2000/XP のコマンドプロンプト で動作する導入適品種判定プログラムを採り上げ, XML Web Service化を行った. 具体的には, XML Web Serviceを実現する仲介ソフトウェアを作成することで, 元の導入適品種判定プログラムには一切の変 更をすることなくWeb対応化することができた.この試験的な実装を通じて, 個々のマシンに散らばっ て存在しているレガシーモデルをXML Web Service化してWeb 対応化することによりモデル統合が可 能であること，また，そのためにXML Web Serviceは有効な手段であることを確認できた.

キーワード

レガシーモデル, モデル統合, XML Web Service, VS. NET, インタネット

\section{はじめに}

既存の各種作物生産支援システムやプログラム と呼ばれるものの多くはスタンドアローン環境で 動作する. すなわち, そのシステムやプログラム は単一のマシン上で動作するように設計・作成さ れており,プログラムコードとそのプログラムが 必要とするデータがそのマシン内に用意されてい るという動作形態である. 一例として 10 年前に 関沢ら（1992）が行った関東東海地域農業試験研 究機関におけるソフトウェアの開発状況調査結果 では, 開発予定のものも含め 400 件余のソフト ウェアが関東東海地域において当時報告されてい る.この報告の契機となった各地域の農業試験研 究機関でまとめられたソフトウェア一覧（農林水 産省農業研究センター 1988, 同北陸農業試験場 1989, 同北海道農業試験場 1991）も含めると非常 に多くのソフトウェアが存在していたことが分か る. それらの仕様概要を調べてみると, 多くは, 当時主流であった PC9801 シリーズの N88-BASIC やMS-DOS 上の BASIC 環境, dBASE-III などの DBMS
環境で作成され動作していたことが分かる．も ちろん, PC9801 用ではなく他のパソコンや大型 機を利用したシステムも存在していた．使用す るデータの種類や書式なども多様で, たとえ類 似したシステムであっても互換性がない場合が ほとんどで, プログラム移植や再利用の際の障 害となっていた.これらの内, 現在動作可能なソ フトウェア，または現役で使用されているソフ トウェアがどれだけ残っているかという点は不 明であるものの, 非常に数多くの開発が行われ 使用されてきたことは明らかであり, 同時に現 在埋もれて眠っているソフトウェアもかなりの 数に上るものと考えられる.

その後, 通信技術の進歩や規制緩和に伴う普 及と低価格化の好循環によりインタネットとい うネットワークコンピューティング環境が定着 し, 現在ではコンピュータのネットワーク利用 は当然のものとなっている（石田 1998）. 作物 生産の現場においても, インタネット利用は進 展しつつあり，またそれに対する期待も大きい。 
農林水産省統計情報部（2002）が行ったアンケー 卜調査によると，作物生産現場におけるインタ ネット利用に関しては「栽培技術等の生産管理情 報の収集」および「市況・気象等の情報収集」に 特に関心が集まっている.

その一方で，Web を利用した栽培技術や市沉・ 気象等の情報提供サイトにとどまらず，地域の $\mathrm{JA}$ や各種団体，機関，農業者などによる様々な目 的の農業関連情報発信サイトが急速に増えつつあ る.たとえば，星（1999）による「植物生産のた めのインタネット道しるべ」サイトでは，本稿執 筆の 2002 年 10 月現在で約 2500 件の作物生産関倸 サイトが登録されている。このような作物生産関 係ポータルサイトや, Googleに代表される汎用検 菜サイトの存在により，インタネット上に公開さ れている農業関連情報についても検索を行うこと はできる.

しかし，いざ検索してみると，真に欲しい情報 にはなかなか行き当たらない場合が多い。この背 景には，発信される情報の内容がWeb サイトに よって様々であり, 戦略的・系統的に整理された 情報提供が行われていないこと，そもそも作物生 産現場からの関心・期待に応えられるような作物 生産関係コンテンツがまだ不十分であるといら状
況がある。これには，農業という産業が，他産業 に比して，自然環境下で生物を再生産するとい う人間活動であることに起因する複雑さ・あい まいさを備えていることが影響している（二宮 2000).

そこで，筆者らは，単一マシン上でしか動作し なかった各種作物生産支援システムやプログラ ム（以下，レガシーモデルと呼ぶ）をWeb経由で 利用できるように改造することで, 作物生産関 係コンテンツの充実を図り, 作物生産現場から のインタネット利用に対する期待に応えること を考えた．これには，今まで眠っていたモデル， または開発者の独自利用に限定されていたモデ ルを, 広く公開し, 作物生産現場からの評価を得 られるようにするという副次的祆らいもある。 公開されることにより，モデルが改善され，さら に普及寸るといった相乗効果も期待できるから である。

さらに，筆者らは，レガシーモデルの有効利用 を踏まえた上で, 図 1 に示すような複数のモデル が連携協調動作寸る総合的な地域統合型営農・ 生産支援システムの構築考目指している。この システムについての議論は本稿の目的ではない ので省略するが，構築に当たっては，既存のソフ

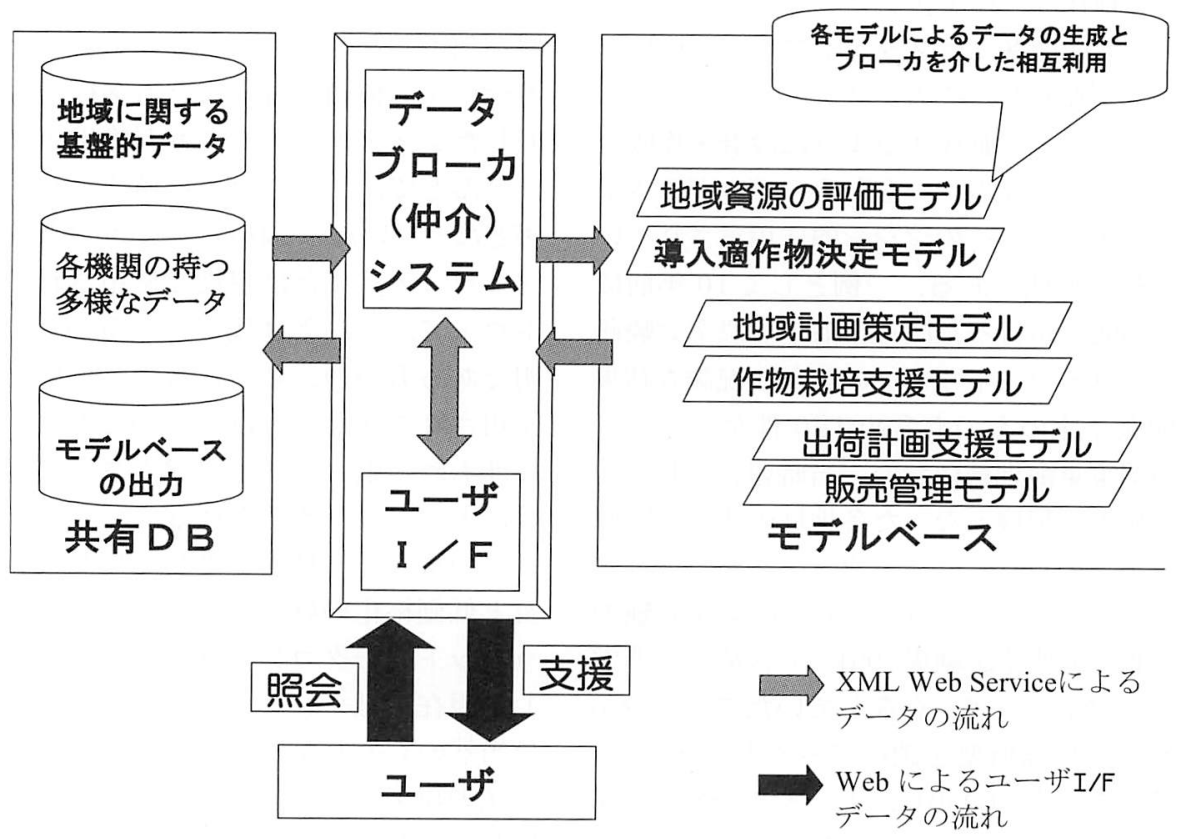

図 1 地域統合型営農生産支援システムの構成 (構想図) 
トウェアで利用可能なものはできるだけ持ち寄っ て活用するとともに，共有可能なデータもできる だけ共有して, 開発資源の重複や無駄をできる限 り省いた効率的な構築を行う必要があると考えて いる，この場合, 個々のモデルやデータセットの 内, 共有可能なものは共通の部品, すなわちコン ポーネントとして配置し，それらをインタネット 上に可能な範囲で公開し相互利用していくという 流れの中でのボトムアップな構築を考えている.

本稿では,このボトムアップな構築の手始めと して, レガシーモデルの Web 対応化による有効活 用事例と, それを踏まえたモデル統合の進め方に ついて述べたい.

\section{インタネット対応化のための諸技術とモデ ル統合に向けた考え方}

レガシーモデルを活用するために, これをイン タネット対応に改造する場合, 適用可能な技術体 系は数多くあるが，筆者らは，インタネット上で 既に広く普及し，普遍性・拡張性をもっている Web およびその拡張技術体系を出発点とした。 そ こで，レガシーモデルの Web 対応化を考えた場 合, モデルそのものをアプレットなどのモバイル コードで実現し，クライアント側にダウンロー ドして実行する形態と, モデルをサーバ側で実行 し，クライアント側では必要最小限のユーザイン タフェイスのみを実行する形態がある（三輪 1996).

前者の形態を採る実装技術体系としては，Java アプレットやBeans, ActiveX Control などがあ り, これらのモバイルコードはWeb サーバからク ライアント側にダウンロードされ Web ブラウザ内 でスクリプトなどと協調しながら動作する.

田中ら（1999）による農業モデルベース開発は この典型的な事例である.ここで開発されたモデ ルは Java 言語で記述され，それぞれが Javaアプ レットとして動作することにより，Web ブラウザ とスクリプトだけでは実現できなかった複雑・高 度な処理やアプレット間の連携動作によるモデル 統合が可能になっている. しかし，これらの機能 を実現するために，モデルそのものをJava 言語 で書き直す必要があった.このためには，モデル に関する知識に加え, 元のモデルを記述していた
プログラミング言語とアプレットを記述するた めの Java 言語の両方の知識と, 書き直すための 時間が必要となる. この事例の内, ナシの生育モ デルの書き換えに 1 週間を要し, 約5000行のソー スコードの内, 半分の 2500 行を新たに記述した とのことである. この例からも分かるように, レ ガシーモデルをWeb ブラウザ上のモバイルコー ドとして実装するためには，ソースコードの大 幅な書き換えが必要である. ほとんどの場合, 全 面書き換えが必要となるであろう.

また，この実装体系では，クライアント側に モデルがダウンロードされて実行されるため, モデルのサイズによっては起動までに時間がか かること，実行時にWeb サーバとの間でデータ 転送が必要になる場合がある，などの理由によ るクライアントーWeb サーバ間のトラフィック 増加が懸念される.さらに，クライアント側端 末の機種や仕様によっては動作しない場合があ り，携帯端末などに対しては，モデルを専用に 作成し直す必要がある.

これに対して, 後者の実装技術体系では, クラ イアント側のブラウザ上に必要最小限のユーザ インタフェイスを配置し，ユーザからの入力に 対しWebサーバ側でモデルを実行し, その結果を Webサーバを通じてクライアント側に返す．この ため, クライアント側端末に対する制約が少な いという特長を持つ. また, Webサーバ側でモデ ルを実行するための Web サーバ拡張技術体系に は, CGI (Common Gateway Interface), ASP (Active Server Pages), JSP (Java Server Pages), Servlet, EJB(Enterprise Java Beans) や分散オブジェクト技術体系としての JavaRMI (Remote Method Invocation), CORBA(Common Object Request Broker Architecture)などが提 唱され実用されている (Orfali et al. 1998).

Laurenson et al. (2000a, 2000b)は, MetBroker の開発により, 仕様の異なる複数の気 象データシステムに同一のインタフェイスでの アクセスを可能とした。 これはWebサーバを直接 拡張する例ではないが，個々の気象データシス テムをデータ提供を行うモデルと見なした場合， それぞれに異なるデータ仕様を持つモデルへの アクセスインタフェイスを統一することにより， 冒頭で述べたモデルの共有化・部品化を図った 
例である. 田中ら (2000, 2001) はこの MetBroker を用いて植物の生育モデルや病害予測モデルの開 発を行い, MetBrokerにより気象データの取得が 効率化されたことを実証している．但し， MetBroker の統一されたインタフェイスは JavaRMI により実装されているため, 使用する場 合は, Java 言語で, 目的とするモデルや気象デー タ取得などのアプリケーションを作成する必要が ある. 既存レガシーモデルの活用を考えた場合に は，やはり，プログラミング言語に依存したソー スコードの書き換えが必要となる.

そこで，ある程度のソースコード書き換えは避 けられないとしても, 最小限の変更で斉むように するために, レガシーモデルと Web サーバ拡張技 術の仲介を行うソフトウェアを開発することでレ ガシーモデルのW e b 対応化を考えた。これは MetBroker が仕様の異なる気象データシステムを JavaRMI インタフェイスに仲介する機能を果たし ていることと同様であり，ここで開発される仲介 ソフトウェアによりレガシーモデルの機能をWeb 上で利用可能なインタフェイスに変換すること で，Web 上におけるレガシーモデルの部品化・共 有化を目指すものである.

この際，そのインタフェイスの実装に， MetBroker のように, JavaRMI を用いることも可 能であるが, 前述したようにプログラミング言語 依存の問題があるので, できるだけプログラミン グ言語に依存しない，言い換えれば，プログラミ ング言語中立な技術体系が実装体系としては望ま しいと考えた. 幸い, 近年特に, ファイアウォー ル関連のセキュリティ面で取り扱いやすく, Web との親和性も高いXML Web Serviceが注目されて いる（丸山ら 2001，仙石ら 2002）。この技術体系 は，その名が示すとおり，XMLが基本となってお り，プログラミング言語中立という特長を備え, We b 上での部品化・共有化を可能とするインタ フェイス(API：Application Programming Interface) を備えたサービスを作成・提供するも のである（栗原 2001, 実森 2002).

このような技術体系により，モデルの機能が部 品化され共有可能なインタフェイスを備えたサー ビスとしてインタネット上に公開されると, 次の 段階として，それらを複数のモデル間で利用する
ことが可能となってくる.これによりモデル間 の連携が図られ, 図 1 に示したような複数のモデ ルやデータセットからなる総合的なシステムの 構築が可能となる.

\section{レガシーモデルのXML Web Service化事例}

今回，手始めとしてXML Web Service化する 題材として選んだレガシーモデルは, 図 1 中の導 入適作物決定モデルである。本モデルは， Windows NT/2000/XP のコマンドプロンプトで動 作する単一EXEファイル形式のプログラムで, 機 能的には気候的類似性に基づいて露地野菜の栽 培適地判定を行うものである (大原ら 2002). 動 作に必要なデータはすべて個別のファイルから 入力し, 判定結果もすべて個別のファイルに出 力するようになっている (図 2 破線内).

このモデルのXML Web Service化に当たって, ユーザが指定する入力パラメータは，作物名 (現時点ではキャベツのみ), 品種名（キャベッ 46 品種), 判定地点 (緯度経度) の 3 つとした. モデル単体としては，他にも指定可能なパラ メータはあるが, XML Web Service化によりイ ンタネット公開した場合の本モデルのユーザ層 を，農業改良普及員や中核農家など作物生産の 現場で実際に品種導入の意志決定を行う人々と 想定したことから，彼らにとってパラメータの 概念や意味・目的が理解しづらく，また指定が なくても判定結果に大きくは影響しないと考え られるパラメータは除いた.

モデルの出カパラメータについても, 同様の 理由により，指定された判定地点において指定 された作物・品種を栽培した場合の月別作型成 立確率 $(0 \sim 100 \%)$ のみとし，その他のより詳細 な判定結果は除いた.

以上 $4 つ$ 入出カパラメータに基づき, モデル の機能を呼び出す空口となるXML Web Service のインタフェイス仕様を作成し（表 1)，それぞ れのメソッドを実装した. 実装に当たっては, 開 発環境としてVS. NET (マイクロソフト 2002b, 田 中 2002) と Java WSDP (Sun Microsystems 2002) を事前に評価したが，今回は早期に最終版がリ リースされたVS. NET を用いて実装を行った. 開 

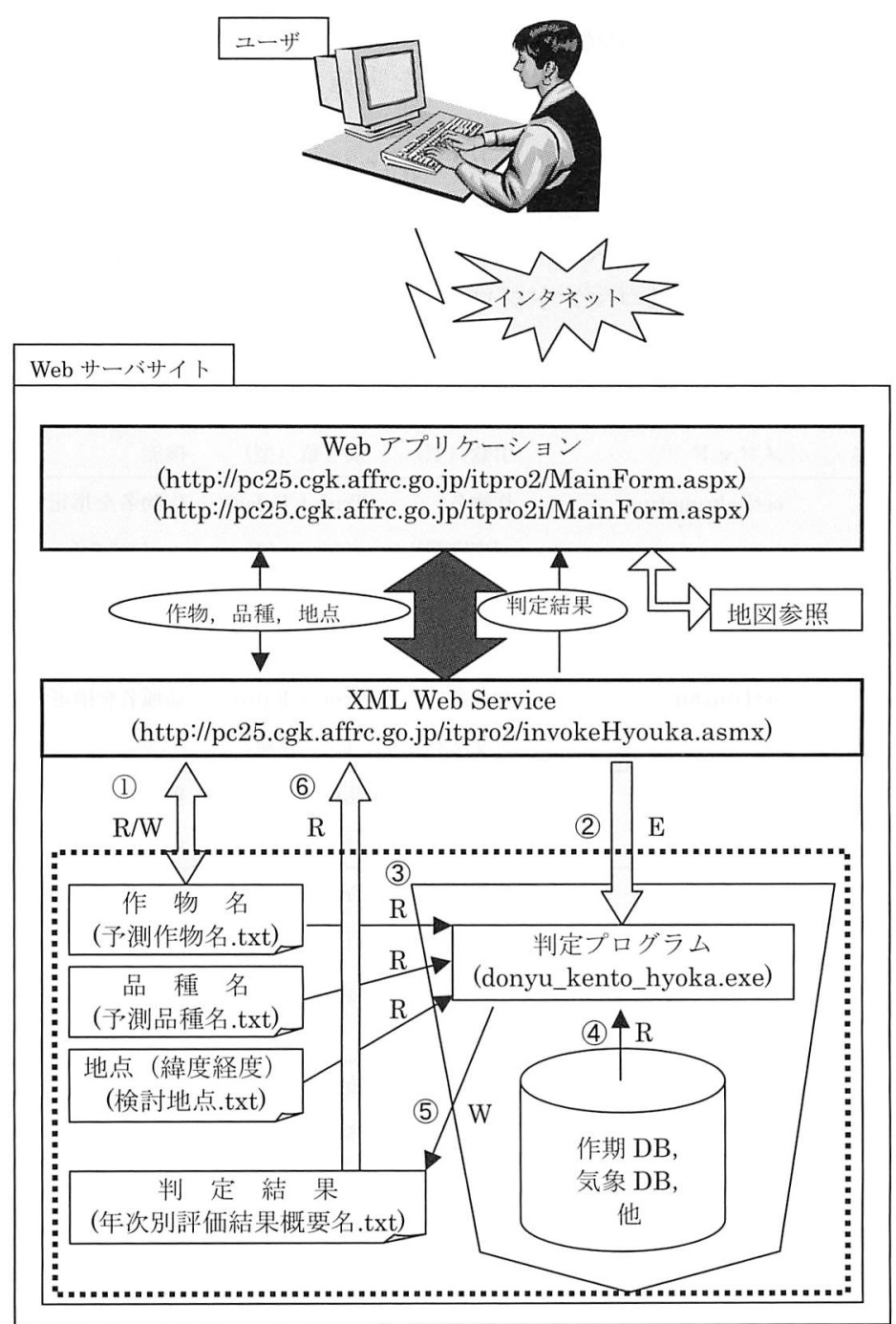

R:Read W:Write E:Execute (1): 実行順序

図2 XML Web Service化されたモデルの全体構成と処理の流れ

発マシンの OS はWindows 2000 Server SP3, Web サーバはIIS 5.0である。

前述したようにXML Web Serviceは，インタ ネット上に公開されたAPIであることから, ユー ザインタフェイスは持たない。このため, 今回想 定しているユーザ層にXML Web Service化された モデルを利用してもらうためのユーザインタフェ イスを持ち, XML Web Service化されたモデルと ユーザとの仲介を行うWeb アプリケーションも同 時に作成した（図 $2 \sim 4$ ).また，無償配布されて
いるMobile Internet Toolkit (マイクロソフ ト 2002a）を用いて, PDA や携带電話などの携帯 端末を対象としたWeb アプリケーションも作成 した (図 5).

以上の, XML Web Serviceとして実装された モデル及びそれを利用するWebアプリケーショ ンから構成される導入適品種判定システムは, 実験公開サイト (http://pc25. cgk. affrc. go.jp/ 以下）においてアクセス可能である. 
XML Web Service化の効果とモデル統合に 向けた課題

今回, XML Web Service化の題材に用いたレガ シーモデルは，コマンドプロンプト下で動作する プログラムであった. キャラクタベースのユーザ インタフェイスを持ち, 動作時にはコマンドプロ
ンプト内に様々な動作状況を表示しながら判定 を実施するが，それらの情報はユーザインタ フェイスのための情報であり, XML Web Service 化によるAPI としてみた場合には，すべて必要の ない情報であった. API として必要な入出力パラ メータはすべて個別のファイルを介して行うよ うになっていたため, コマンドプロンプトで動

表 1 XML Web Service化したモデルのインタフェイス仕様

\begin{tabular}{|c|c|c|c|c|}
\hline インタフェイス & メソッド & 引数 (型) & 戻り值 (型) & 機能 \\
\hline \multirow[t]{13}{*}{ invokeHyouka } & setSakumotu & $\begin{array}{l}\text { 作物名 } \\
\text { (文字列) }\end{array}$ & $\begin{array}{l}\text { True | False } \\
\text { (プール値) }\end{array}$ & $\begin{array}{l}\text { 作物名を指定する（現在は"キ } \\
\text { ヤベツ"のみ }\end{array}$ \\
\hline & getSakumotu & なし & $\begin{array}{l}\text { 作物名 } \\
\text { (文字列) }\end{array}$ & $\begin{array}{l}\text { 現在指定されている作物名を } \\
\text { 返す }\end{array}$ \\
\hline & setHinshu & $\begin{array}{l}\text { 品種名 } \\
\text { (文字列) }\end{array}$ & $\begin{array}{c}\text { True | False } \\
\text { (プール值) }\end{array}$ & 品種名を指定する \\
\hline & getHinshu & なし & $\begin{array}{l}\text { 品種名 } \\
\text { (文字列) }\end{array}$ & $\begin{array}{l}\text { 現在指定されている品種名を } \\
\text { 返す }\end{array}$ \\
\hline & setPosition & $\begin{array}{l}\text { 検討地点緯 } \\
\text { 度, 経度 } \\
\text { (浮動小数 } \\
\text { 点) }\end{array}$ & $\begin{array}{c}\text { True I False } \\
\text { (プール值) }\end{array}$ & $\begin{array}{l}\text { 検討地点の緯度経度を指定す } \\
\text { る }\end{array}$ \\
\hline & getPosition & なし & $\begin{array}{l}\text { 検討地点緯度 } \\
\text { 経度 } \\
\text { (文字列) }\end{array}$ & $\begin{array}{l}\text { 現在指定されている検討地点 } \\
\text { の緯度経度をカンマ区切り文 } \\
\text { 字列として返す }\end{array}$ \\
\hline & execHyoukaIndirect & なし & $\begin{array}{l}\text { True | False } \\
\text { (ブール値 })\end{array}$ & $\begin{array}{l}\text { 現在指定されている作物, 品 } \\
\text { 種, 地点に対して導入適判定を } \\
\text { 実行する（非同期実行） } \\
\text { 判定終了を待たずにリターン } \\
\text { する } \\
\text { 判定結果は getResult メソッ } \\
\text { ドにより得る }\end{array}$ \\
\hline & getResult & なし & $\begin{array}{l}\text { 判定結果 } \\
\text { (文字列) }\end{array}$ & $\begin{array}{l}\text { 直前に実行された判定状況を } \\
\text { チェックし, 判定が終了してい } \\
\text { れば, その結果を返す }\end{array}$ \\
\hline & execHyouka & $\begin{array}{l}\text { 作物名 } \\
\text { 品種名 }\end{array}$ & $\begin{array}{l}\text { 判定結果 } \\
\text { (文字列) }\end{array}$ & $\begin{array}{l}\text { 引数で指定された作物, 品種, } \\
\text { 地点に対して導入適判定を実 }\end{array}$ \\
\hline & & 検討地点緯 & & 行し, 判定結果を返す（同期実 \\
\hline & & 度, 経度 & & 行) \\
\hline & & (文字列) & & 判定結果が出るまでリターン \\
\hline & & & & しない \\
\hline
\end{tabular}




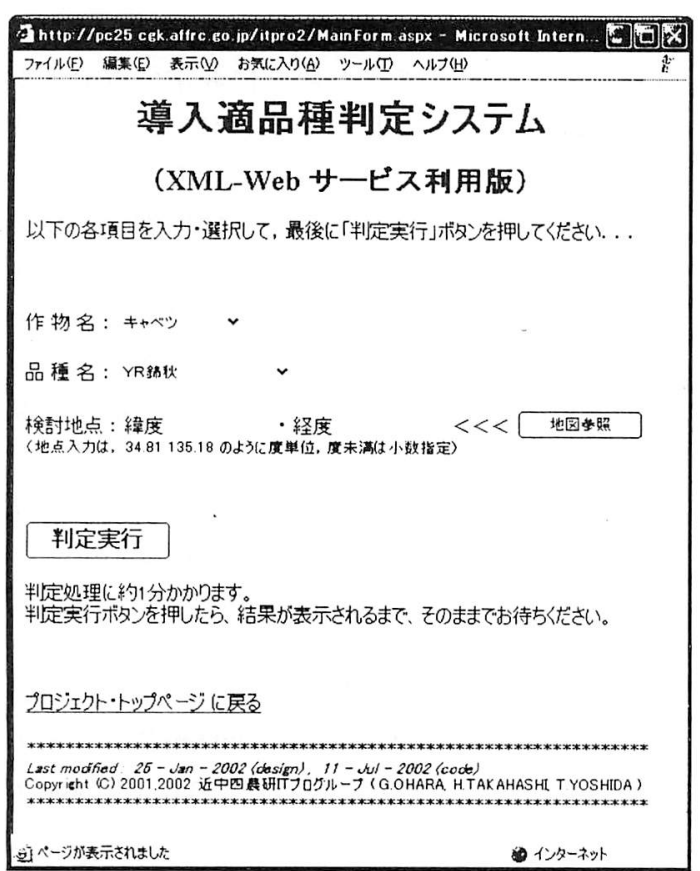

図3 XML Web Service化されたモデルの入力画面 ( ユーザはこの画面において，作物名(キャベッ)，品 種名 (キャベツ46品種)，検討地点(緯度経度)を指定 することにより，月別の作型成立確率を得ることが できる。

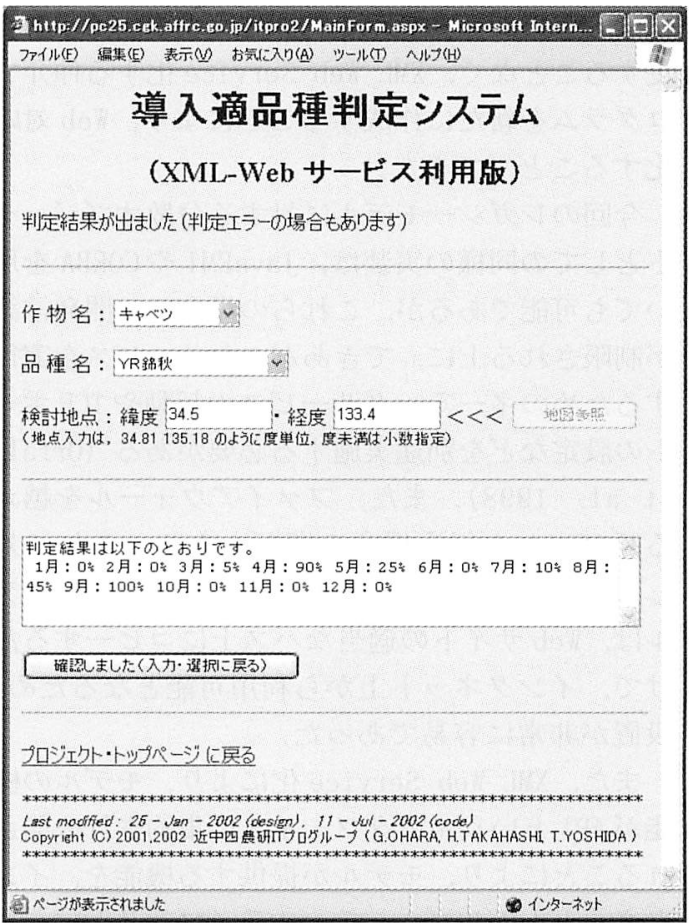

図4 XML Web Service化されたモデルの結果出力画面 (図3で入力されたパラメータ(作物名, 品種名, 検討) 地点)に対する判定結果 (月別作型成立確率)が表示 される.ユーザはこの結果で導入可否を判断する。
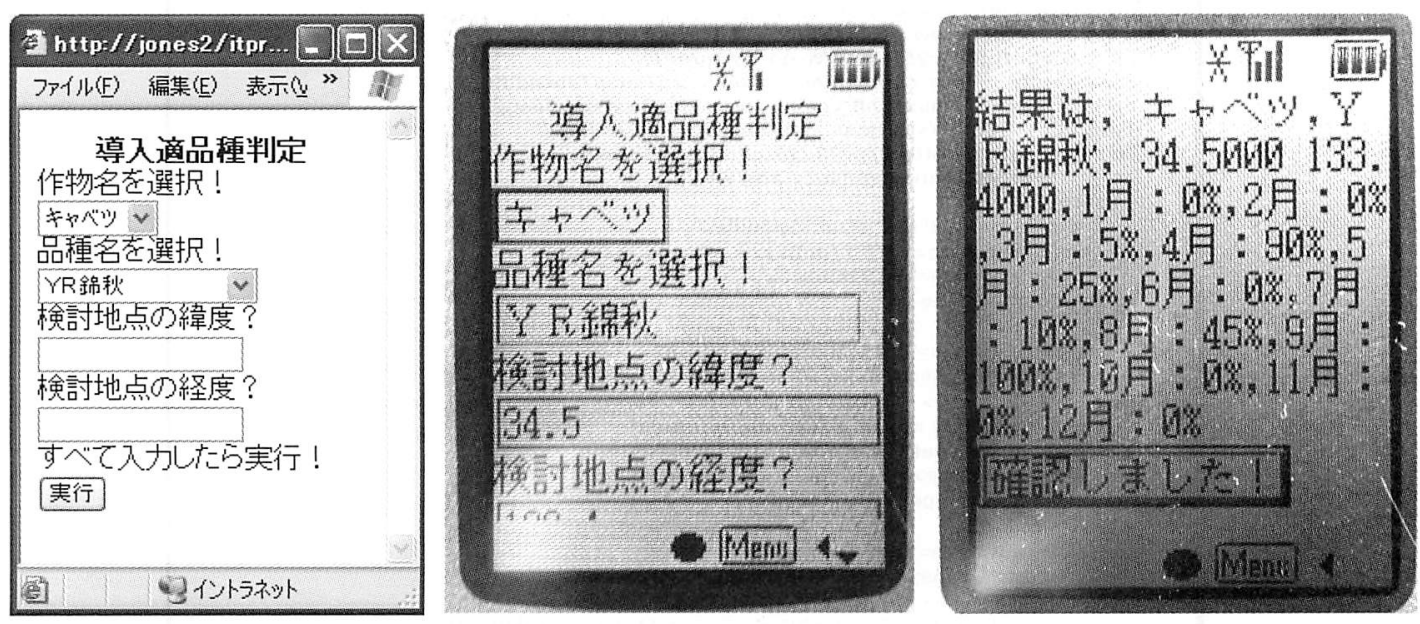

注）URLは”http://pc25.cgk.affrc.go.jp/itpro2i/MainForm.aspx"

\section{図5携带端末用のモデル実行画面}

\footnotetext{
$\left(\begin{array}{c}\mathrm{i} \text { モードなどの携带端末用に作成したモデルのユーザインタフェイス画面. 左は, デスクトップ } \\ \mathrm{PC} \text { の゙ラウザでの表示例. 中央は } \mathrm{i} \text { モード端末におけるモデルの人力画面 (内容は図 } 3 \text { と同様). } \\ \text { 右はそれに対する判定結果の出力画面例である. }\end{array}\right)$
} 
作するレガシーモデルのプログラム本体は一切変 更することなく，XML Web Service化する仲介プ ログラムを新たに作成することにより, Web 対応 化することができた.

今回のレガシーモデルに対する分散オブジェク トとしての同様の実装は, JavaRMI やCORBA を用 いても可能であるが, これらの場合は, 開発言語 が制限される上に，できあがったサービスを実行 するためのネーミングサービスの起動や TCP ポー 卜の設定などを別途実施する必要がある（Orfali et al. 1998). また, ファイアウォールを越え る呼び出しを行う場合の問題もある。これに対 し，今回実装したXML Web Service化されたモデ ルは, Webサイトの適当なパス上にコピーするだ けで,インタネット上から利用可能となるため, 設置が非常に容易であった。

また，XML Web Service化により，モデルの機 能がAPI というインタフェイスに集約され公開さ れることにより，モデルが提供する機能を，イン タネット上のサブルーチンやライブラリという感
覚で，Web 経由で利用できる点は，今後のモデル 連携による統合を考えた場合に非常に有効であ ると考えられた。これらのインタフェイスを使 用したWebアプリケーションの作成やモデル連 携を行う場合，インタフェイス仕様の取得が必 要となる。実装したXML Web Serviceでは, 図 6に示したようにWSDL(Web Service Description Language)により，公開されたXML Web Service に直接アクセスしてインタフェイス仕様を開発 環境内に反映できるようになっている。このた め, 使用するプログラミング言語に関係なく，使 い慣れたプログラミング言語を用いてWeb アプ リケーションの作成に専念できた.

このことは，もう一つの重要な意味を持つ.今 回の実装例もそうであるが, XML Web Serviceは, インタネット上のAPI として, 問題解決のための 機能を担当すると考えられる. これに対しWebア プリケーションは主にユーザインタフェイスを 担当すると考えられるため, この意味でも，モデ ルの部品化が行われているものとみな寸ことが

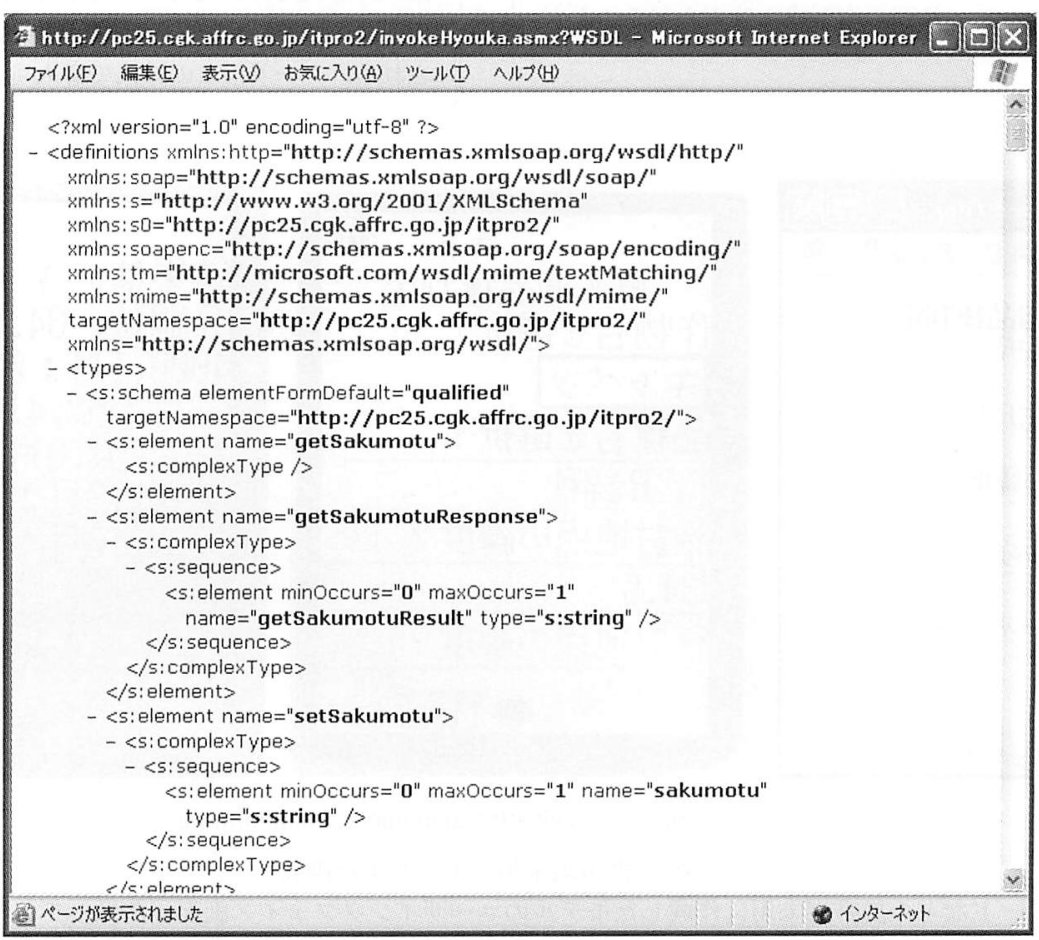

注）URIは”http://pc25.cgk.affrc.go.jp/itpro2ws/invokeHyouka.asmx?WSDL”

図6 XML Web Serviceが出力するインタフェイス仕様 
できる，すでに完成した部品を組み合わせて，新 たなアプリケーションを作るという現在主流と なっているプログラミングスタイルは，ソフト ウェア生産の効率化・低コスト化に大いに貢献し ているからである（大森ら 2002）。

さて，これまでに述べた手法により，既存の各 種モデルをXML Web Service化して，そのイン タフェイスが公開されれば，その機能を部品と して利用するWebアプリケーションの開発にも拍 車がかかるものと期待される. むろん, Webアプ リケーションとして公開されたモデルもインタ ネット上で評価されることにより，モデルその ものの改良にも拍車がかかるものと期待される.

今回の実装では, 露地野菜を対象とした導入適 作物決定モデルの機能をXML Web Service として インタネット上に公開した. また，その機能を利 用するWebアプリケーションを作成してWeb 経由 でユーザインタラクティブに導入適作物の判定を 行うことができた．同様の実装を他のモデルに対 しても施すことにより, 個々のモデルが Web 経由 で利用可能になり, それらの蓄積が作物生産支援 関係コンテンツ不足の解消にもつながるものと考 えている.

また，前記したように，個々のモデルのXML Web Service化により公開されたインタフェイス をモデル間で相互に利用して連携すればモデル統 合という次の段階も実現可能となってくる. しか し, この時, 特に注意しなければならないのは, 各モデルが独自にインタフェイスを定義していく と本質的な改善にならなくなるという危険性であ る. 例えば，作目毎に生育予測を行う複数のモデ ルがそれぞれ独自のインタフェイスを実装し公開 していくと，無秩序なインタフェイスの汇濫状態 に陥り，結局利用したい機能を提供しているモデ ルが見つからないとか, 使いたい機能を公開して いるモデルはいくつかあるのだがインタフェイス が微妙に違っていて面倒だという状況になりかね ない.

この点については, 今回, 一つのレガシーモデ ルのXML Web Service化に取り組んだ段階であ り, 今後, 図1の未着手のモデルに対応していく 過程において, インタフェイスの整合性, グルー プ化などを検討し, XML Web Serviceの集合体と
して構成されるデータブローカに集約していく 必要があると考えている。幸い, XML We b Service 自体がまだ発展途上にある比較的新し い技術体系であるため, 現時点で，作物生産支 援関連の XML Web Serviceを公開しているサイ トはほとんどなく，危惧するような状況にはな い.しかし，非常に注目されている技術体系で あるので，今後XML Web Service を提供する作 物生産支援関連サイトが急速に増えていく可能 性もあり，今の内から動向を慎重に見守りつつ 対応していく必要がある.

\section{引用文献}

星岳彦(1999)植物生産のためのインタネット道しるべ, http://w3.fb.u-tokai.ac.jp/hoshi/igpp.asp.

石田晴久 (1998)インターネットはここまできた一現状と 課題一, 情報処理, 39(5):393-399

実森仁志 (2002)Webサービスの構築が始まる, 日経イン タネットテクノロジー, 58:28-47.

栗原 潔(2001) Webサービスでビジネスが変わる，XML ガジン, 7(15): 36-47.

Laurenson, M., T. Kiura and S. Ninomiya(2000a) Accessing online weather databases from Java, Proc. Internet Workshop2000, 193-198.

Laurenson, M., T. Kiura and S. Ninomiya(2000b) A weather databroker for agricultural decision support, Proc. APAN Conference 2000, 297-306.

丸山 宏・小坂一也・浦本直彦 (2001)Web Servicesに よる動的な電子商取引の実現-SOAP/WSDL/UDDI 一, 情報処理, 42(7)：643-647.

マイクロソフト(2002a) Mobile Internet Toolkit. http:// www.microsoft.com/japan/msdn/vstudio/device/ mitdownload.asp.

マイクロソフト (2002b)Visual Studio.net. http:// www.microsoft.com/japan/msdn/vstudio/default.asp.

三輪芳久 (1996) 第2世代WWWを支える最新技術を解きほぐ す, 日経バイト, 157:166-172.

二宮正士(2000) 21 世紀の農業・農村情報化に向けたソフ トウェア開発と利用, 今月の農業, 44(7): 16-22.

農林水産省統計情報部 (2002) 農家のパソコン・インター ネット利用状況アンケート結果, 農林水産統計速 報, $13-275$ (構造-5).

農林水産省農業研究センター(1988)関東東海地域農業関 倸試験研究機関開発ソフトウェア一覧1987年版.

農林水産省北陸農業試験場 (1989) 北陸地域農業関係試験 研究機関ソフトウェア一覧1989年版. 
XML Web Service化によるレガシーモデルの統合

農林水産省北海道農業試験場 (1991) 北海道地域農業関係 ソフトウェアー覧.

大原源二 ・高橋英博 - 吉田智一 (2002) 発育段階毎の気候 的類似性に基づく適作型・導入適品種の判定, 農業 環境工学関連 4 学会2002年合同大会講演要旨, 226.

大森敏行・八木玲子 (2002) プログラミング言語の明日, 日経バイト, 233:71-95.

Orfali, R. and D. Harkey(1998) Client/Server Programming with Java and CORBA(2nd ed), 日経BP, 東京, 430pp.

関沢邦夫 - 代永道裕 - 伊藤 稔(1992)関東東海地域農業 試験研究機関におけるソフトウェアの開発状況につ いて, 農業研究センター研究資料, $24: 1-80$.

仙石 誠・中道 理(2002)インターネットの限界を超え る, 日経バイト, $224: 62-85$.

Sun Microsystems, Inc. (2002) Java Web Services Developer Pack, http://java.sun.com/webservices/ webservicespack.html.

田中 慶・乙部和紀・平藤雅之 (1999) Javaによる農業モ デルベースの開発，農業情報利用別冊， 10:139140.

田中 慶・M. Laurenson - 渡邊朋也 - 平藤雅之 (2000) MetBrokerを利用した生育モデルの開発，農業情報 利用別冊, 12:117-118.

田中 慶・M. Laurenson・平藤雅之 (2001) Javaによる植 物の生育・病害予測モデルの構成と開発手法, 農業 情報利用別冊, 13:74-75.

田中正造 (2002) XMLを基盤にした統合開発環境, XMLマガ ジン, 8(2):24-33.

受付日：2002 年 9 月 10 日 受理日：2002年 12 月 20 日 


\title{
A Method of Integrating Distributed Legacy Models by Applying XML Web Service
}

\author{
Tomokazu Yoshida, Hidehiro Takahashi and Genji Ohara \\ National Agricultural Research Center for Western Region \\ National Agricultural Research Organization \\ 6-12-1, Nishi-Fukatsu, Fukuyama, Hiroshima, 721-8514 Japan
}

\section{Summary}

To increase the agricultural content available through the Internet, we discuss applying XML Web Services as a method of integrating distributed legacy models in stand-alone machines. First, we discuss the advantages of XML Web Services in comparison with other similar Web extension methods. Next, we describe a practical experiment in which we applied XML Web Service to a legacy model, which was a standard program running under the command prompt of Windows NT/2000/XP and had no network access, in order to examine the capability of XML Web Service to convert legacy models into modern ones fitting the Internet environment. We implemented a web application and an XML Web Service application wrapping the functions of the program without modifying it. Though this practical implementation, we confirmed the capability of XML Web Services as a method of integrating distributed legacy models.

\section{Keywords}

legacy model, integration of distributed models, XML Web Service, VS.NET, internet 